\title{
Çoğul İlaç Dirençli Acinetobacter baumannii İzolatlarının Pulsed-Field Gel Elektroforezis İle Klonal İlişkisinin Araştırıması
}

\section{The Investigation of Clonal Relationship Among Multiple Drug Resistant Acinetobacter baumannii Isolates with Pulsed-Field Gel Electrophoresis}

\author{
Mehmet Reșat CEYLAN 1 (D), Mustafa Kasım KARAHOCAGiL2 ${ }^{\mathbb{D}}$, Alper KARAGÖZ ${ }^{(\mathbb{D})}$, \\ Aytekin ÇIKMAN 4 (D), Rıza DURMAZ 5 (D)
}

\begin{abstract}
1 Harran Üniversitesi Tıp Fakültesi, Enfeksiyon Hastalıkları ve Klinik Mikrobiyoloji Ana Bilim Dalı, Şanlıurfa 2 Ahi Evran Üniversitesi Tıp Fakültesi, Enfeksiyon Hastalıkları ve Klinik Mikrobiyoloji Ana Bilim Dalı, Kırşehir 3 Uşak Üniversitesi Fen Edebiyat Fakültesi, Moleküler Biyoloji ve Genetik Bölümü, Uşak 4 Erzincan Binali Yıldırım Üniversitesi Tıp Fakültesi, Tıbbi Mikrobiyoloji Bölümü, Erzincan 5 Ankara Yıldırım Beyazıt Üniversitesi Tıp Fakültesi, Tıbbi Mikrobiyoloji Anabilim Dalı, Ankara
\end{abstract}

Öz.

Amaç: Bu çalışma ile, yoğun bakım ünitelerinde yatan hastalardan izole edilen A.baumannii suşlarının antibiyotiklere direnç oranının saptanması ve hastane enfeksiyonu etkeni çoklu ilaç direncine sahip izolatların klonal ilişkisinin, pulsed-field jel elektroforez (PFGE) yöntemi kullanılarak gösterilmesi amaçlandı.

Materyal ve Metod: Yüzüncü Yı Üniversitesi Tıp Fakültesi Hastanesi; Anesteziyoloji ve Reanimasyon Yoğun Bakım Ünitesi (AYBÜ), Göğüs Hastalıkları Yoğun Bakım Ünitesi ve Pediatri Yoğun Bakım Ünitesi'nde Ocak 2010-Ekim 2011 tarihleri ve AYBÜ'de Temmuz-Kasım 2012 tarihleri arasında takip edilen A. baumanii ile oluşan, Ventilatör İlişkili Pnömoni (VIP) ve Primer Kan Dolaşımı Enfeksiyonu (PKDE) tanısı alan 69 hasta ve aynı sayıda izolat çalışmaya alındı.

Bulgular: Çalışmaya dahil edilen 69 hastanın 35'i erkek $(\% 50,7)$ ve 34'ü $(\% 49,3)$ kadındı. Hastaların yașları 1-86 arasında değișmekte idi (ortalama yas 54). Hastaların 63 (\%91) tanesi ViP, 6 (\%9) tanesi ise PKDE tanısı almıșıı. Tüm hastalara YBÜ yatışı boyunca en az iki invaziv girişim uygulanmıştı. Üriner kateterizasyon $(\% 100)$, mekanik ventilasyon $(\% 94,2)$ ve periferik venöz kateterizasyon $(\% 91,3)$ en sık uygulanan invaziv girişimlerdi. Antibiyotik duyarıııkları imipenem, kolistin ve tigesiklin için E-test, diğer antibiyotikler için disk difüzyonla çalışıldı. Tüm suşlar için en duyarlı antibiyotik kolistin $(\% 98,6)$ idi. Daha sonra tigesiklin $(\% 97,1)$ ve levofloksasin $(\% 69,6)$ gelmekteydi. Suşların tamamı seftriakson, piperasilin/tazobaktam, meropenem ve imipeneme dirençli bulundu. A.baumannii izolatlarının Apal ile kesilen genomik DNA'sına yapılan PFGE analizi ile, 69 A.baumannii suşunun 62 (\%89,9)'sinin küme içinde olduğu saptandı. Bu suşlar 16 küme içinde yer almakta idi. Suşların 7 (\%10,1)'si özgül PFGE profili gösterdi ve suşlar arasında 23 pulsotip saptandı.

Sonuç: Çoğul ilaç dirençli A.baumannii izolatlarının kümeleşme oranının yüksek bulunması ve benzer genotipteki izolatların farklı ünitelerdeki hastalardan izole edilmesi bu bakterinin hastanemiz YBÜ' lerinde endemik duruma geçtiğinin göstergesidir. Önlem alınmadığı takdirde A.baumannii uzun yıllar boyunca hastanelerde kalabilmekte ve hastalar arasında kolaylıkla bulaş olabilmektedir. Özellikle çapraz bulaşın önlenmesi için enfeksiyon kontrol programlarının gerekliliği ve önemi bir kez daha vurgulandı.

Anahtar Kelimeler: A.baumannii, direnç, PFGE

Abstract

Background: With this study, the detection of the resistance rates of A.baumannii strains isolated from the patients in the intensive care units to the antibiotics and the demonstration of the clonal relationship of the isolates with multi-drug resistant of the factor of nosocomial infection were aimed by using the method of pulsed-field gel electrophoresis (PFGE).

Materials and Methods: At the Medical Faculty Hospital of Yüzüncü Yıl University, 69 patients followed between January 2010-October 2011 at the Intensive Care Unit of Anesthesiology and Reanimation (ICUAR), Intensive Care Unit of Chest Diseases and Pediatric Intensive Care Unit and July-November 2012 at ICUAR and the same number of isolates formed with A.baumanii, Ventilator Associated Pneumonia (VAP) and diagnosis of Primary Bloodstream Infection (PBI) were enrolled to the study.

Results: Of the 69 patients included in the study, 35 were men (50.7\%) and 34 (49.3\%) were women. The ages of the patients ranged from 1 to 86 years (mean age 54). 63 (91\%) of the patients were diagnosed with VAP and $6(9 \%)$ of them with PBI. At least two invasive interference had been performed to the all patients during the staying at the ICU. Urinary catheterization (100\%), mechanical ventilation (94.2\%) and peripheral venous catheterization (91.3\%) were the most frequently performed invasive interferences. Antibiotic susceptibilities to imipenem, colistin and tigecycline were studied with the E-test and to the other antibiotics with the disk diffusion. Colistin was the most effective antibiotic for all of the strains (98.6\%). Then, tigecycline (97.1\%) and levofloxacin (69.6\%) were in the second place. All of the strains were resistant to ceftriaxone, piperacillin/tazobactam, meropenem and imipenem. With the PFGE analysis of A.baumannii isolates performed to the genomic DNA cut with Apal, it was found that 62 of the 69 A.baumannii strains (89.9\%) were within the cluster. These strains were located within 16 clusters. 7 of the strains $(10.1 \%)$ showed the profiles of specific PFGE and 23 pulsotip were detected among the strains.

Conclusion: Being high of clustering rate of multidrug-resistant $A$. baumannii isolates and isolating the isolates in similar genotypes from the patients in different units is the indicator of these bacteria to be endemic situation in the ICUs of our hospital. If precautions are not taken, $A$. baumannii has been able to remain in the hospitals for many years and can be easily transmitted among the patients. Especially for the prevention of cross-contamination, the necessity and importance of infection control programs have once again emphasized.

Key words: A. baumannii, resistance, PFGE

\section{Sorumlu Yazar I \\ Corresponding Author}

Mehmet Reşat CEYLAN

Harran Üniversitesi Tıp Fakültesi

Enfeksiyon Hastalıkları ve Klinik

Mikrobiyoloji A.D,

63100, Osmanbey Kampüsü-

Şanlıurfa

Fax: +904143183190

Tel; 05069931563

e-mail;dr.mresatceylan@gmail.com.tr

Geliş tarihi / Received:

24.06.2020

Kabul tarihi / Accepted:

14.08.2020

DOI: 10.35440/hutfd. 757137
4-7 Haziran 2014 tarihleri arasında Ankara'da yapılan 8. Ulusal
Moleküler ve Tanısal Mikrobiyoloji Kongresi'nde poster bildiri olarak sunulmuştur. 


\section{Giriş}

Acinetobacter cinsi bakteriler zorunlu aerop, hareketsiz, non-fermentatif, Gram-negatif çomaklardır (1). Acinetobacter türleri doğada toprak, bitkiler, su ve yiyeceklerde saprofit olarak serbest yaşayabilmektedirler (2). Hastane ortamında uzun süre canlı kalması, farklı ISı ve pH derecelerinde yaşayabilmesi, kuru ortamlara dayanıklı olması ve hastadan hastaya kolaylıkla bulaşabilmesi nedeniyle son yıllarda A.baumannii yoğun bakım üniteleri (YBÜ)'nde giderek artan oranda hastane enfeksiyonlarına (HE) neden olmaktadır. Aynı zamanda antimikrobiyallere karşı kolaylıkla direnç geliştirebilmesi nedeniyle kontrolü zor epidemilere yol açabilmektedir (3). Hastaneye yatan hastalarda solunum yolları kolonizasyon ve enfeksiyon açısından en önemli yerleşim yeridir (2,3). Ayrıca deri ve gastrointestinal sistem kolonizasyonuda önemli oranda tespit edilmiştir $(4,5)$. Hastanelerin mobilya ve ekipmanları gibi çevresel ortamlarda ikincil rezervuar yerleridir (3).

A.baumannii özellikle girişimsel tanı ve tedavi araçlarının yoğun bir şekilde kullanıı ı̆ğı YBÜ'de yatan hastalarda, sorunlu enfeksiyonlara yol açmaya devam eden firsatçı bir patojendir. A.baumannii' nin antibiyotik direnci yıllar içinde tüm dünyada artış göstermektedir. Avrupa da karbapenem direnci \%50-85 oranlarında iken, ülkemizde bazı merkezlerde bu oran \%90'ların üzerine çıkmıştır (6-10). En sık alt solunum yolu enfeksiyonlarına neden olurlar. Birçok çalışmada ventilatörle ilişkili pnömoni ve kateterle ilişkill kan dolaşımı enfeksiyonlarının en sık nedeni oldukları gösterilmiştir (11-13). Travma, mekanik ventilasyon, trakeotomi, invaziv girişimler, çoklu antibiyotiklere maruz kalma ve dirençli mikroorganizmalarla kolonizasyon gibi nedenler hastane kökenli $A$. baumannii enfeksiyonların artmasındaki başlıca risk faktörleridir (14).

Acinetobacter türlerinin, özellikle çoğul ilaç dirençli olanlarında tedavi seçeneklerinin kısıtlı olması, kolonizasyonun genelde enfeksiyona öncülük etmesi, sıklıkla önlenmesi zor salgınlara neden olması ve yüksek mortaliteden dolayı Acinetobacter enfeksiyon/kolonizasyonu için risk faktörlerinin belirlenmesi ve bu risk faktörlerine yönelik önlem alınması büyük önem taşımaktadır.

Geçmiş̧e farklı kaynaklardan izole edilen nozokomiyal patojenlerin arasındaki epidemiyolojik ilişkilerin belirlenmesi, fenotipik karakteristiklerinin karşılaştırımasına dayandırılıyordu. Bu yaklaşım moleküler analiz uygulamalarındaki gelişmeler ışığında son üç dekatta hızlı bir şekilde değişim göstermeye başladı (15). Özellikle dirençli suşların moleküler epidemiyolojik metodlarla klonal düzeyde sürveyansı, yeni ve daha etkin kontrol tedbirlerinin geliştirilmesine ışık tutacak, mevcut kontrol tedbirlerinin de gözden geçirilerek revize edilmesine sebep olacaktır.

Günümüzde kullanılan birçok moleküler yöntemin yanında, A.baumannii'nin genotiplemesinde Pulsed-Field Jel Elektroforez (PFGE) tekrarlanabilirliği ve yüksek ayrım gücü gibi özellikleri nedeniyle altın standart yöntem olarak kabul görmüştür. Bu yöntemi uygulamada eğitimli personel gereksinimi, özel ekipman ihtiyacı, uzun ve meşakkatli süren işlemlere sahip olması ve sonuçların değerlendirilmesinde standardizasyonların henüz sağlanmamış olması yöntemin dezavantajlarındandır (15).

Bu çalışma ile, hastanemiz yoğun bakım ünitelerinde yatan hastalardan izole edilen $A$. baumannii suşlarının antibiyotiklere direnç oranının saptanması, çoğul ilaç dirençli olan suşların PFGE ile genotiplemesinin yapılarak suşlar arasında klonal ilişkinin olup olmadığının belirlenmesi, bu sonuçlar ile hastaların epidemiyolojik ve klinik verileri değerlendirilerek A.baumannii ile oluşan hastane kökenli enfeksiyonlar için risk faktörlerinin belirlenmesi, mortalitesi ve maliyeti yüksek olan bu enfeksiyonun özelliklerinin incelenmesi ve önlenmesi için değerlendirme yapılması amaçlanmıştır.

\section{Materyal ve Metod \\ Hastalar ve A.baumanii İzolatları; Çalışmamıza, Hasta-} nemizin Anesteziyoloji ve Reanimasyon Yoğunbakım Ünitesi (AYBÜ), Göğüs Hastalıkları Yoğunbakım Ünitesi (GHYBÜ) ve Pediatri Yoğun Bakım Ünitesi (PYBÜ)'nde Ocak 2010- Ekim 2011 tarihleri ve AYBÜ'de Temmuz-Kasım 2012 tarihleri arasında takip edilen nozokomiyal Acinetobacter türlerine bağlı Ventilatör İlişkili Pnömoni (VIP) ve Primer Kan Dolaşımı Enfeksiyonu (PKDE) tanısı alan hastalar ve bu hastalardan Merkez Bakteriyoloji Laboratuvarı'na gönderilen derin trekeal aspirat (DTA) ve kan kültür örneklerinden üreyen çoğul ilaç direnci olan A.baumanii izolatları kabul edildi. Hastaların bilgileri retrospektif olarak hasta dosyaları, Enfeksiyon Kontrol Ekibi (EKE), hastane ve yoğun bakım kayıt sisteminden elde edildi. Kültür materyellerinde Acinetobacter spp. üreyen bütün hastalar, hastanemiz Enfeksiyon Kontrol Komitesi tarafından değerlendirilerek Hastalık Kontrol ve Korunma Merkezi [Centers for Disease Control and Prevention (CDC)] kriterlerine göre hastane enfeksiyonu (HE) olup olmadıklarına karar verildi (16). Hastaların yatışları süresince ilk enfeksiyon atağı değerlendirmeye alındı. Bir hastanın aynı dönemde farklı kültür numunelerinde üreyen birden fazla bakteri olduğu durumlarda çalışmaya sadece bir numunede üreyen A.baumannii izolatları alındı. Kolonizasyon veya kontaminasyon olarak değerlendirilen kültür sonuçları çalışmaya alınmadı. Bu çalışma Van Yüzüncüyı Üniversitesi Bilimsel Araştırma Projeleri Başkanlı̆̆ tarafından 2012-TFU037 numaralı proje olarak desteklenmiş ve Van Yüzüncüyıl Üniversitesi İlaç Dışı Klinik Araştırmalar Etik Kurul Başkanlığı'nın 09.05.2013 tarih ve 08 no'lu etik kurul kararı ile çalışmaya başlanmıştır.

Bakterilerin Tanımlanması ve Antibiyotik Duyarlılık Testleri; Merkez Bakteriyoloji Laboratuvarı'na gelen klinik örnekler \%5 koyun kanlı agar ve Eozin Metilen Blue (EMB) agar kültür ortamlarına ekilerek $18-48$ saat $37^{\circ}{ }^{\circ}$ 'de 
etüvde inkübe edildi. Kan kültürleri ise BACTEC 9120 BD (Becton Dickinson, $\mathrm{ABD}$ ) otomatize kan kültürü sistemi ile çalışıldı. Üreme gösteren örnekler kan kültürü şişelerinden uygun katı besiyerine ekilerek yine $18-48$ saat $37^{\circ} \mathrm{C}$ 'de etüvde inkübe edildi. İnkübasyon sonrası $\% 5$ koyun kanlı agar ve EMB agarda saf koloni halinde üreyen bakteriler konvansiyonel yöntemlerle identifiye edildi. Aerob, non-fermenter (glukoz ve laktozu fermente etmeyen) üreme özelliği gösteren ve Gram boyamasında Gram-negatif koko-basil veya diplokok morfolojisinde saptanan, TSI besiyerinde dipte ve yatıkta alkali reaksiyon veren, Simons sitrat besiyerinde üreyerek besiyerinin rengini maviye dönüştüren, hareket besiyerinde hareketsiz olarak tespit edilen, Indol testi negatif bakterilerin Acinetobacter spp. olabileceği düşünüldü. Daha sonra Phoneix 100 BD (Becton Dickinson, ABD) identifikasyon sistemi ile suşların otomatize tip tayini yapıldı. A.baumannii olarak tiplendirilen suşların antibiyotik direnci disk difüzyon ve E-test yöntemleri ile çalışıldı.

Disk Difüzyon Yöntemi; Suşların antibiyotik duyarlııkları Muller Hinton Agar (MHA) (Oxoid, İngiltere) ve standart antibiyotik diskleri (Oxoid, Ingiltere) kullanılarak CLSI M02A11'e göre Kirby-Bauer disk difüzyon yöntemiyle yapıldı ve inkübasyonu takiben elde edilen sonuçlar CLSI M100S23'e göre yorumlandı (17-18). Test için dört mm kalınlığında dökülmüş Muller Hinton Agar (MHA) besiyeri kullanıldı. Kanlı agarda üreyen saf $A$. baumannii suşları steril serum fizyolojik içerisinde; yoğunluğu türbidometrik yöntemle 0,5 McFarland olacak şekilde (Oxoid turbidometer, İngiltere) süspanse edildi ve steril eküvyon yardımı ile agar yüzeyine ekim yapıldı. Antibiyotik diskleri dispenser (Oxoid, Ingiltere) ile birbirlerine uzaklıkları standart $25-30 \mathrm{~mm}$ olacak şekilde yerleştirildikten sonra petriler $37^{\circ} \mathrm{C}$ 'de $18-24$ saat inkübasyona bırakıldı. İnkübasyon sonrasında her antibiyotik için inhibisyon zon çapı milimetrik olarak ölçülerek; test sonuçları, CLSl'ın önerdiği sınırlara göre duyarlı (S), orta duyarlı (I) ve dirençli (R) olarak değerlendirildi (18). Kalite kontrol olarak $P$. aeruginosa ATCC 27853 suşu kullanıldı.

E-Test Yöntemi; Disk difüzyon yöntemi ile çoğul dirençli olarak değerlendirilen A.baumannii suşlarının imipenem, kolistin ve tigesikline duyarlııklarının Minumum İnhibisyon Konsantrasyonu (MIK) düzeyinde saptanması için E-test yöntemi kullanıldı. Çalışmaya alınan MDR A.baumannii kökeninin her biri ile steril serum fizyolojik içerisinde $0.5 \mathrm{Mc}$ Farland bulanıkıkta süspansiyon hazırlandı. Bu süspansiyondan steril eküvyon ile MHA besiyeri içeren $15 \mathrm{~cm}$ çapındaki plak yüzeyine yaygın ekim yapıldı. Plaklar kuruduktan sonra imipenem, kolistin ve tigesiklin stripleri (Etest-bioMeriux, ABD) yerleştirildi. Plaklar $37^{\circ} \mathrm{C}$ de, 1824 saat inkübe edildikten sonra E-test striplerinin inhibisyon elipsleri ile kesiştiği noktalardaki MiK değerleri okunarak kaydedildi. Imipenem ve kolistin için elde edilen MiK değerleri CLSI'nin önerileri doğrultusunda değerlendirildi. Buna göre E-test striplerinin MiK değeri imipenem için; $\geq 16$ $\mu \mathrm{g} / \mathrm{ml}$ ise dirençli, $8 \mu \mathrm{g} / \mathrm{ml}$ ise orta derecede duyarlı ve $\leq 4$ $\mu \mathrm{g} / \mathrm{ml}$ ise duyarlı kabul edildi. Kolistin için MiK değerleri ise; $\geq 4 \mu \mathrm{g} / \mathrm{ml}$ olduğunda dirençli, $\leq 2 \mu \mathrm{g} / \mathrm{ml}$ olduğunda duyarlı olarak değerlendirildi (18). Tigesiklin için CLSI standartları olmadığından Food and Drug Administration'in (FDA) Enterobacteriaceae'lerde önerdiği ( $\leq 2 \mathrm{mg} / \mathrm{L}$ duyarlı, $4 \mathrm{mg} / \mathrm{L}$ orta duyarlı ve $\geq 8 \mathrm{mg} / \mathrm{L}$ dirençli) kriterlere göre değerlendirildi (19). Çoğul ilaç dirençli A.baumannii izolatları moleküler çalışmada kullanılmak üzere boncuklu tüpler (Cryoinstant, Deltalab, İspanya) içerisine alınarak çalışma başlanıncaya kadar $-80^{\circ} \mathrm{C}$ 'de buzdolabında (Sanyo, Japon) saklandı.

\section{Acinetobacter baumannii'nin PFGE Uygulaması ile Moleküler Tiplendirme}

Çalışmanın moleküler tiplendirme aşaması; Türkiye Halk Sağlığı Kurumu, Moleküler Mikrobiyoloji Araştırma ve Uygulama Laboratuarı'nda gerçekleştirildi. PFGE uygulaması Seifert ve arkadaşlarının (20) standardize ettikleri protokol esas alınarak, Durmaz ve arkadaşlarının (21) küçük modifikasyonlar yaptıkları protokole göre yapıldı. Biyokimyasal ve/veya moleküler yöntemlerle tür düzeyinde tanımlaması yapıımış A.baumannii izolatları hücre süspansiyonu içinde hazırlandı. Agaroza gömülmüş bakteriyal DNA Apal restriksiyon endonüklez enzimiyle kesilerek PFGE yöntemiyle analiz edildi. Elektroforez işleminde, CHEF-DR II sistemi (Bio-Rad Laboratories, Nazareth, Belgium) kullanıldı. Uygulanan elektoforez koşulları: Başlangıç vuruş süresi 5sn, bitiş vuruş süresi $20 \mathrm{sn}$, vuruş açısı $120^{\circ}$, akım $6 \mathrm{~V} / \mathrm{cm}^{2}$, sıcaklık $14^{\circ} \mathrm{C}$, süre 19 saat idi.

PFGE sonrası bant profillerinin dendogram analizleri, Bionumerics Gel Compare II yazilım sistemi (Version 3.0, Applied Maths, Belçika) kullanılarak bant profilleri analiz edildi. Benzerliklerin hesaplanmasında Dice benzerlik katsayısı ile \%1 tolerans değerleri kullanılarak dendogram oluşturuldu ve kümelenme analizi yapıldı. Klonal ilişki, Tenover ve ark. (22) önerdikleri kriterlere göre değerlendirildi. Analizde \%90-100 uyum gösteren izolatlar aynı; \%80-90 arası uyum gösterenler yakın ilişkili; \%70-80 arası uyum gösterenler muhtemel ilişkili ve \% 70 'in altında uyum gösterenler ise ilişkisiz olarak kabul edildi.

\section{İstatistiksel Analizler}

Üzerinde durulan özelliklerden sürekli değişkenler için tanımlayıcı istatistikler; ortalama, standart sapma, minimum ve maksimum değerler olarak ifade edilirken, kategorik değişkenler için sayı ve yüzde olarak ifade edildi. Hesaplamalar için SPSS (ver.13) istatistik paket programı kullanıldı.

\section{Bulgular}

Epidemiyolojik İlişki ve Risk Faktörlerine Ait Bilgiler; Bir üniversite hastanesi AYBÜ, GHYBÜ ve PYBÜ'de yatan A.baumannii nedenli Ventilatör İlişkili Pnömoni (VIP) ve Primer Kan Dolaşımı Enfeksiyonu (PKDE) tanısı doğrulan- 
mış, hastane kayıtlarına ulaşılabilen 72 hasta ve 72 A.baumannii izolatı çalışmaya alındı. 3 izolatın PFGE ile tiplendirmesi yapılamadığından çalışmaya 69 hasta ve izolat ile devam edildi.

Çalışmaya dahil edilen 69 hastanın 35'i erkek $(\% 50,7)$ ve 34 'ü $(\% 49,3)$ kadındı. Hastaların yaşları 1-86 arasında değişmekte idi (ortalama yaş 54). Acinetobacter'ler sıklıkla 61-80 yaş aralı̆ı̆ındaki hastalardan izole edildi. Acinetobacter izolatlarının $41(\% 59,4)$ tanesi AYBÜ, $24(\% 34,8)$ tanesi GHYBÜ ve $4(\% 5,8)$ tanesi PYBÜ'de izole edildi. Örneklerin $45(\% 65,2)$ 'i derin trakeal aspirat ve $24(\% 34,8)$ 'ü kan kültüründen izole edildi. Bu izolatlardan $29(\% 42)$ tanesi 2010, $28(\% 40,6)$ tanesi 2011 ve $12(\% 17,4)$ tanesi 2012 yllına aitti.

Hastaların 63 (\%91) tanesi VIP, 6 (\%9) tanesi ise PKDE tanısı almıştı. Hastaların hastaneye yatış nedenleri arasında; akciğer ve toraks hastalıkları (\%58) ilk sırada, daha sonra travmalar $(\% 20,3)$ ve Santral sinir sistemi hastalıkları $(\% 18,8)$ gelmekte idi. Tüm hastalara YBÜ yatışı boyunca en az iki invaziv girişim uygulanmıştı. Üriner kateterizasyon (\%100), mekanik ventilasyon $(\% 94,2)$ ve periferik venöz kateterizasyon $(\% 91,3)$ en sık uygulanan invaziv girişimlerdi (Tablo 1).

Tablo 1. Çalışmaya dahil edilen hastaların genel özellikleri.

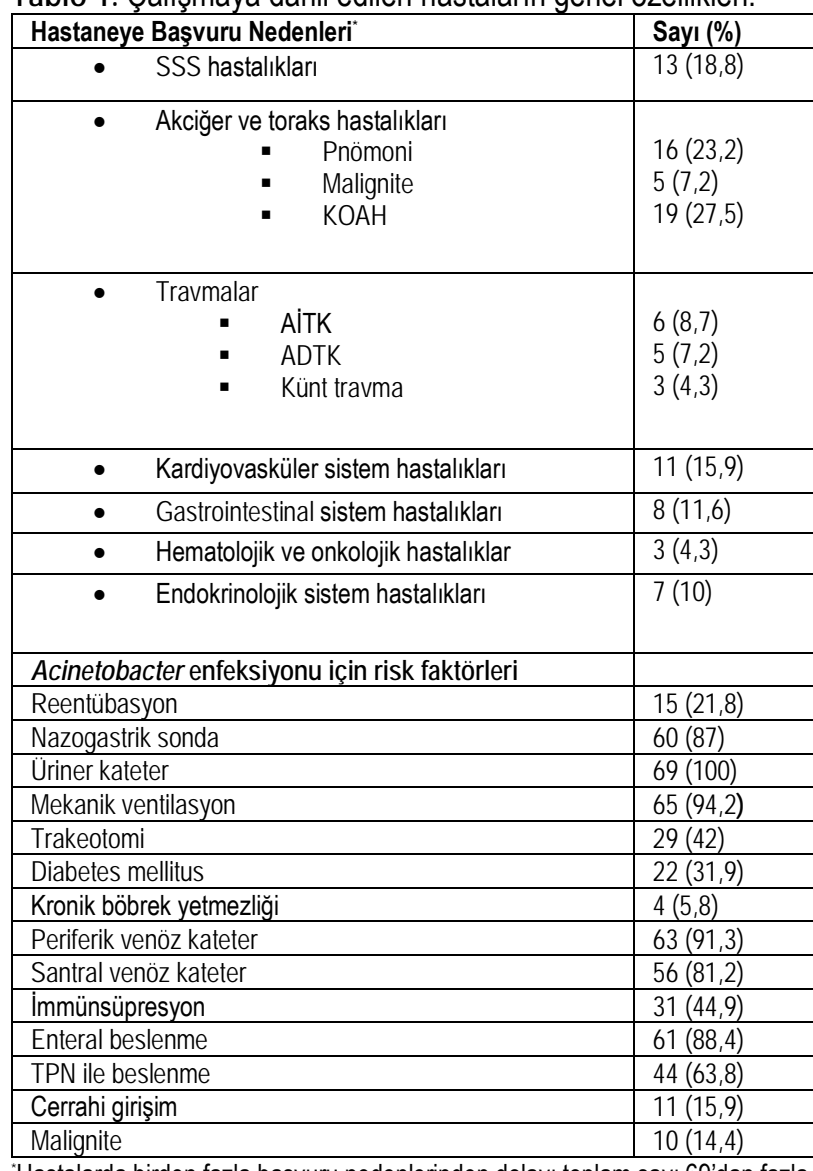

*Hastalarda birden fazla başvuru nedenlerinden dolayı toplam sayı 69 'dan fazladir.
Hastaların $41(\% 59,4)$ ' inin son üç ay içinde hastaneye yatış öyküsü ve $53(\% 76,8)$ ' ünün birden fazla antibiyotik kullanma öyküsü vardı. YBÜ'ye yatan hastaların 65 $(\% 94,2)$ 'ine invaziv mekanik ventilasyon uygulanmıştı. Mekanik ventilasyon günü kültür öncesi ortalama $17 \pm 12.9$ gün ve kültür sonrası ortalama $14 \pm 12$ gün idi. Hastalarda YBÜ'ye yatışlarının ortalama 17. gününde A.baumannii'ye bağlı enfeksiyon gelişti. $65(\% 94,2)$ hasta YBÜ'de kültür alındığında birden fazla grup antibiyotik kullanmakta idi. Siprofloksasin $(\% 47,8)$, piperasilin-tazobaktam $(\% 40,6)$ ve karbapenemler $(\% 37,6)$ en çok kullanılan antibiyotiklerdi. Hastalar ortalama 33,4tstandart sapma gün YBÜ'de yatmıştı. $16(\% 23,2)$ hasta taburcu edilmiş, $53(\% 76,8)$ hasta kaybedilmişti.

A.baumannii İzolatlarının Antibiyotik Duyarlılık Sonuçları; Disk difüzyon ve E-test ile yapılan duyarlıklık testlerinde; tüm suşlar için en etkili antimikrobiyal ajan \%98,6 duyarlılık oranı ile kolistin olarak tespit edildi. Íkinci sırada ise tigesiklin (\%97) vardı. Suşların tamamı piperasilin/tazobaktam, seftriakson, meropenem ve imipeneme dirençli bulundu (Tablo 2). Test edilen suşlardan üç veya daha fazla grup antibiyotiğe (MDR) dirençli suş sayısı 60 (\%87), kolistin ve tigesiklin hariç (XDR) diğer antibiyotiklere dirençli 8 $(\% 11,6)$ ve çalışılan tüm antibiyotiklere (PDR) dirençli 1 $(\% 1,4)$ suş bulundu.

Tablo 2. A. baumannii izolatlarının antibiyotiklere karşı direnç durumu

\begin{tabular}{|l|l|l|l|l|}
\hline & \multicolumn{2}{|l|}{ Disk Difüzyon Testi } & \multicolumn{2}{c|}{ E-test } \\
\hline Antibiyotik & $\begin{array}{l}\text { Direnç } \\
\text { (n:69) }\end{array}$ & $\begin{array}{l}\text { Yüzde } \\
\text { (\%) }\end{array}$ & $\begin{array}{l}\text { Direnç } \\
\text { (n:69) }\end{array}$ & Yüzde (\%) \\
\hline $\begin{array}{l}\text { Ampisilin/sulbak- } \\
\text { tam }\end{array}$ & 66 & 95,7 & & \\
\hline $\begin{array}{l}\text { Piperasilin/tazo- } \\
\text { baktam }\end{array}$ & 69 & 100 & & \\
\hline $\begin{array}{l}\text { Tikarsilin/ } \\
\text { klavulanik asit }\end{array}$ & 64 & 92,8 & & \\
\hline Seftazidim & 66 & 95,7 & & \\
\hline Sefepim & 66 & 95,7 & & \\
\hline Sefotaksim & 69 & 100 & & \\
\hline Seftriakson & 69 & 100 & & \\
\hline Levofloksasin & 48 & 69,6 & & \\
\hline Meropenem & 69 & 100 & & 100 \\
\hline Gentamisin & 64 & 92,8 & & 1,4 \\
\hline Amikasin & 59 & 85,5 & & 2,9 \\
\hline Siprofloksasin & 66 & 95,7 & & \\
\hline $\begin{array}{l}\text { Trimetoprim/ } \\
\text { sülfametoksazol }\end{array}$ & 52 & 75,4 & & \\
\hline İmipenem & 69 & 100 & 69 & 1 \\
\hline Kolistin & & & 2 & \\
\hline Tigesiklin & & & & \\
\hline
\end{tabular}

Moleküler Tiplendirme; A.baumannii izolatlarının antibiyogram tiplendirilmesi yapıldıktan sonra genotipik tiplendirilmesi amacıyla yapılan PFGE çalışmasında A.baumannii DNA'ları Apal restriksiyon enzimiyle kesildikten sonra çeşitli bant paternlerinin görüldüğü PFGE jel görüntüleri ortaya çıktı (Şekil 1 ve 2 örnek olarak gösterilmektedir).

PFGE bant profillerininin sergilendiği A.baumannii suşlarının jel görüntülerinden bir sonraki aşamada dendogram 
analizi yapıldı. Gel-Compare-II kullanılarak yapılan bant profil analizinden sonra PFGE profil dendogramları oluşturularak Dice benzerlik katsayısına göre suşlar arasındaki ilişkiler belirlendi. Bu istatiksel analizde \%90-100 uyum gösteren suşlar aynı; \%80-90 arası uyum gösterenler yakın ilişkili; \%70-80 arası uyum gösterenler muhtemel ilişkili olarak değerlendirildi. \%70'in altında uyum ise ilişkisiz olarak kabul edildi.

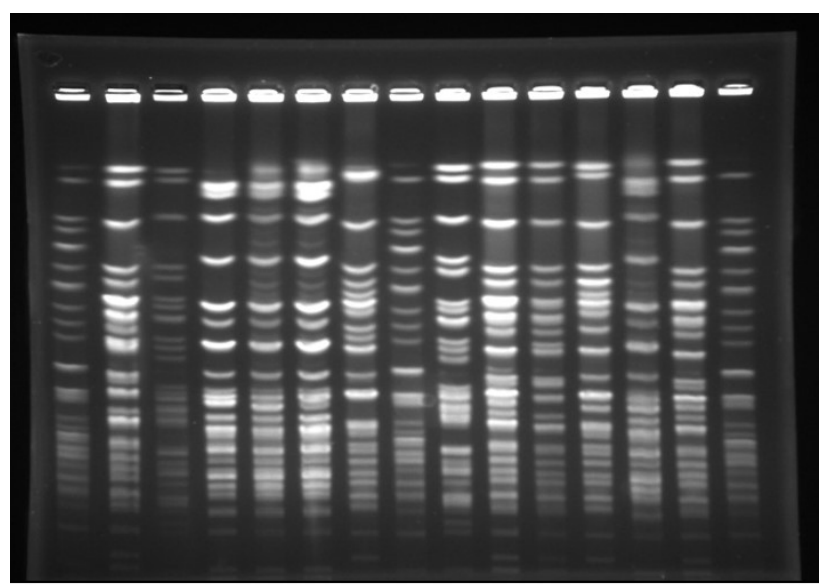

$\begin{array}{llllllllllllll}M & 1 & 2 & 3 & 4 & 5 & 6 & M & 7 & 8 & 9 & 10 & 11 & 12\end{array}$

Şekil 1. PFGE 1.grup; 1, 2, 3, 4, 5, 6, 7, 8, 9, 10, 11, 12 No'lu suşlara ait PFGE görüntüleri. M: Marker; kontrol suşu

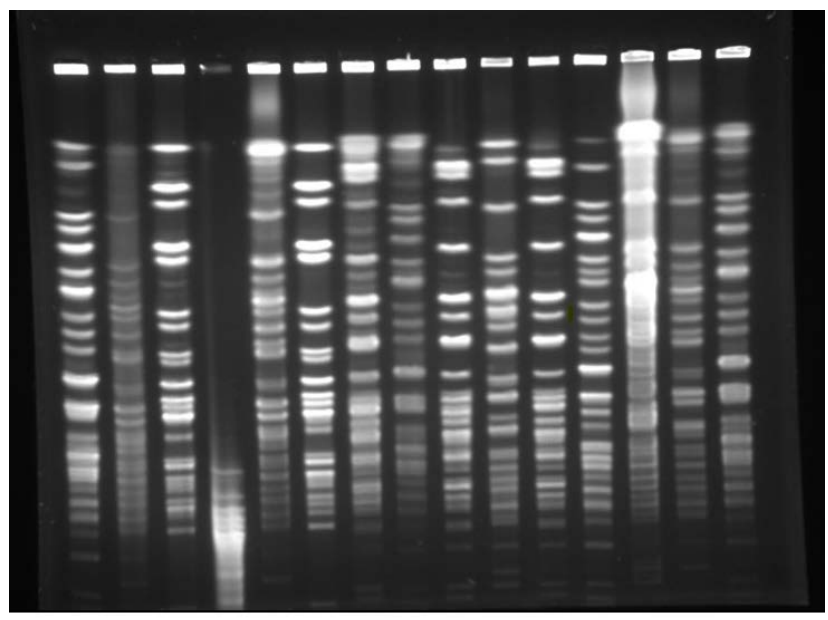

M 6061 Y 626364 M 65666768 Z 69 M

Şekil 2. PFGE 6.grup; 60, 61, 62, 63, 64, 65, 66, 67, 68, 69 No'lu suşlara ait PFGE görüntüleri. Y ve $Z$ izolatları iki kez çalışılmasına rağmen jel görüntüleri iyi alınamadı

PFGE ile tiplendirilmesi yapılan 72 suşun üç tanesinden düzgün bant görüntüleri alınamadı. İki kez aynı protokol ile çalışımasına rağmen sonuç alınamadı. PFGE yöntemiyle 69 A.baumannii suşunun 62(\%89,9)'sinin küme içinde olduğu saptandı. Bu suşlar 16 küme içinde yer almakta idi. Suşların 7(\%10,1)'si özgül PFGE profili gösterdi. Kümeleşmede suş aralığı 2-9 arasında değişmekte idi.
Tiplendirmeye alınan suşlar arasında 23 pulsotip saptandı. Hasta ve A.baumannii suşları aynı numara ile adlandırlarak kümelere göre yorumları yapıldı (Hasta no;1, suş no;1). A.baumannii izolatlarının PFGE dendogram görüntüsü çıkarıldı (Şekil 3).

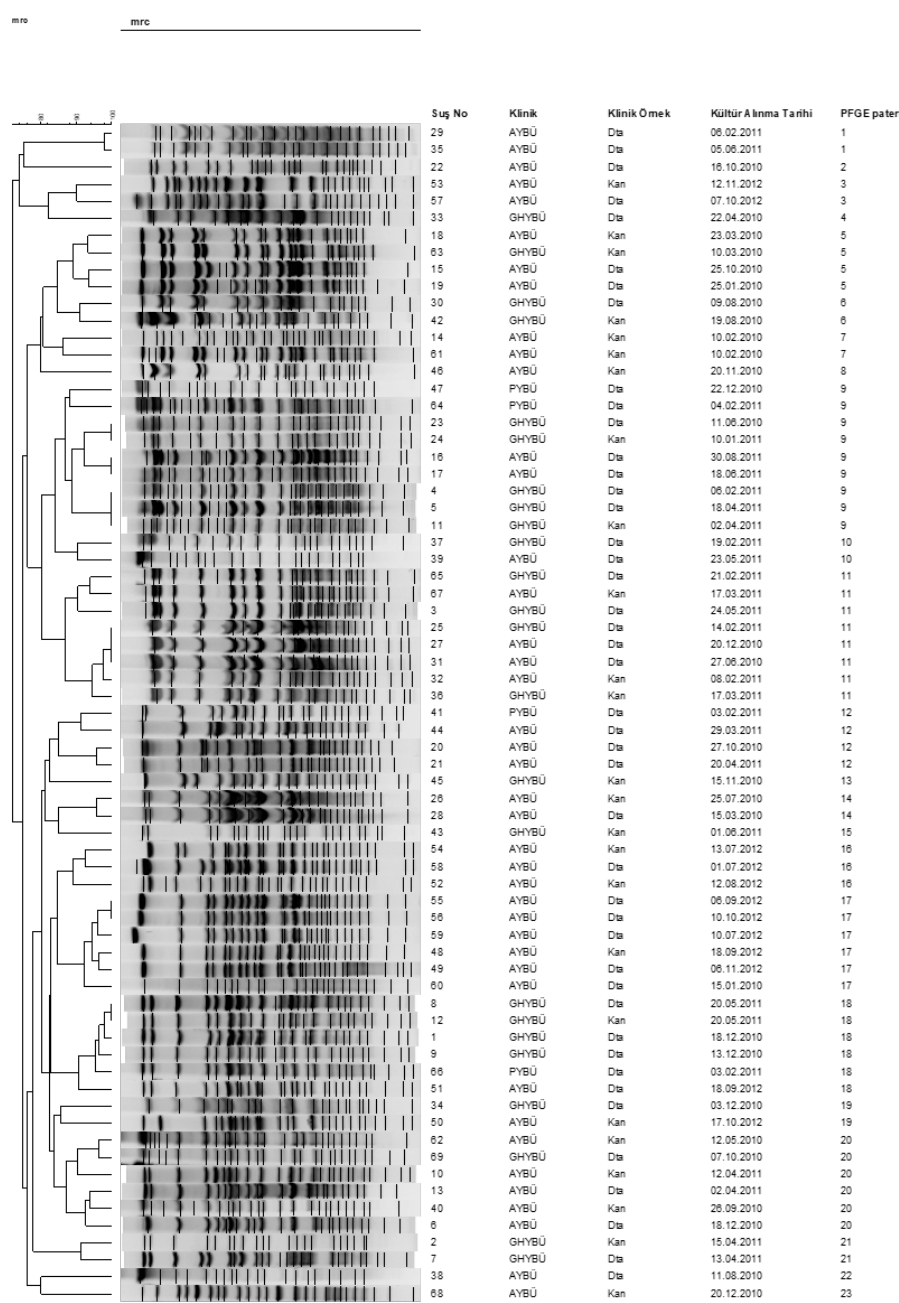

Şekil 3. A. baumannii izolatlarının PFGE dendogram görüntüsü

Küme İçinde Yer Alan Suşların Epidemiyolojik İlişkileri; Aşağıda 16 küme içinde yer alan ve suş sayıları yüksek olan birkaç küme ve epidemiyolojik ilişkilerinden bahsedilecektir.

Üçüncü küme (Patern 5): Dört suş içermektedir (18, 63,15 ve 19 nolu). Bu kümedeki ilk suş (19 nolu) 25.01.2010 tarihinde AYBÜ'de izole edildi. 18 ve 15 no'lu suşlar bir ve dokuz ay sonra aynı ünitede izole edildi. 63 nolu hasta Ocak 2010 da AYBÜ'de hematolojik malignite tanısıyla yatmış, daha sonra Dahiliye servisine yatırımış. Şubat 2010 da kardiyak arrest gelişen hasta entübe edilerek GHYBÜ'ye alınmış. 10.03.2010 tarihinde ViP gelişen hastanın kan kültüründe 63 nolu suş izole edildi.

Altıncı küme (Patern 9): En fazla suş içeren küme olup dokuz suş içermektedir $(47,64,23,24,16,17,4,5$ ve 11 
nolu). 4, 5 ve 11 nolu izolatlar aynı suş olarak değerlendirildi. İlk suş 06.02.2011 tarihinde GHYBÜ'de izole edilmiş, diğer iki suş iki ay sonra aynı ünitede izole edilmişti. 16 ve 17 nolu suşlar aynı suşlar olup Haziran ve Ağustos 2011 tarihlerinde AYBÜ'de izole edilmişti. 23 ve 24 nolu suşlar aynı suşlar olup ilk suş Haziran 2010 tarihinde GHYBÜ'de, ikinci suş yedi ay sonra aynı ünitede izole edildi. 47 ve 64 nolu izolatlar yakın ilişkili olup, aralık 2010 ve şubat 2011 tarihlerinde PYBÜ'de izole edildi.

Bu kümedeki izolatlar kendi içerisinde yakın ilişkili olup ilk suş (23 nolu) 11.06.2010 tarihinde GHYBÜ'de izole edilmiş, bu suş tüm yoğunbakım ünitelerini dolaşarak 14 ay sonra 30.08.2011 tarihinde AYBÜ'de izole edilmişti. Bu klondaki suşlar üç YBÜ'de de izole edildiler.

Sekizinci küme (Patern 11): Sekiz suş içermektedir (65, $67,3,25,27,31,32$ ve 36 nolu). Bu kümedeki 25,27 ve 31 nolu izolatlar aynı suş olarak değerlendirildi. İlk suş (31 nolu) 27.06.2010 tarihinde AYBÜ'de izole edildikten sonra ikinci suş altı ay sonra aynı ünitede izole edildi. Üçüncü suş ilk izolattan sekiz ay sonra 14.02.2011 tarihinde GHYBÜ'de izole edildi. Bu kümedeki klon en son 11 ay sonra GHYBÜ'de 24.05.2011 tatarihinde izole edildi.

On ikinci küme (Patern 17): Altı suş içermektedir $(55,56$, $59,48,49,60$ nolu). Aynı zamanda 11. küme ile muhtemel ilişkilidir. Illk suş (60 nolu) hastanemiz eski binasında AYBÜ'de 15.01.2010 tarihinde izole edildi. İkinci suş (59 nolu) yeni binada AYBÜ'de 10.07.2012 tarihinde izole edildi. Diğer suşlar (55, 56, 48, 49 nolu) sonraki dört aylık dönem içinde yeni binadaki AYBÜ'de izole edildiler. Bu klon AYBÜ'de (eski ve yeni bina) 34 ay süre ile varlığını sürdürdü.

On üçüncü küme (Patern 18): Altı suş içermektedir $(8,12$, 1, 9, 66, 51 nolu). Kümedeki suşlardan ikisi (1, 9 nolu) 2010 Aralık ayında $\mathrm{KOAH}$ akut alevlenmesi nedeniyle GHYBÜ'de yatan iki ayrı hastanın derin trekeal aspirat(DTA) kültürlerinden izole edildi. Daha sonda Şubat 2011'de PYBÜ'de görülen suş (66 nolu), Mayıs 2011 de tekrar GHYBÜ'de aynı gün kültürleri alınan ViP tanılı iki ayrı hastanın (8, 12 nolu) kan ve DTA kültürlerinden izole edildi. Bu klondaki son suş (51 nolu) 13.09.2011 tarihinde AYBÜ'de izole edildi. Bu klondaki suşlar üç YBÜ'de de izole edildiler.

\section{Tartışma}

Artmış morbidite ve mortalitenin yanı sıra, uzamış hastanede kalış süresi, giderek artan direnç oranları ve yüksek tedavi maliyetleri ile ilişkili Acinetobacter enfeksiyonları, hastane de yatan hastaların sağlığını tehdit eden önemli bir sorundur $(12,23)$. Bu sorun ile mücadelede, konağa ait etmenlerin, etkene ait yaşam döngüsünün ve etkenin epidemiyolojik özelliklerinin, etken-hasta-ortam ilişkilerinin, bakterinin tedavi seçeneklerine karşı gösterdiği direncin mekanizmasının ve yayılımının belirlenmesi ana unsurların başında gelmektedir.
Yoğun bakım imkanlarının artması ve buna paralel olarak YBÜ'lerde daha ağır hastaların takip edilmesi, hastaların konak savunmasının bozulması, mekanik ventilasyon, trakeotomi, entübasyon, damar içi kateterizasyon ve üriner kateter gibi invaziv girişimlerin daha sık olması, çoklu antibiyotiklere maruz kalma ve dirençli mikroorganizmalarla kolonizasyon gibi nedenler hastane kökenli enfeksiyonların YBÜ'de artmasındaki başlıca risk faktörleridir (14).

Acinetobacter yakın bir zamana kadar enfeksiyona nispeten kolonizasyon yapma kapasitesi daha yüksek olan, düşük virülanslı bir mikroorganizma olarak bilinmekteydi. Fakat günümüzde A.baumannii başta olmak üzere Acinetobacter türlerinin enfeksiyon oluşturma yeteneklerinin yüksek olduğu ve bu etkenlere bağlı hastane kökenli enfeksiyonların tüm dünyada hızla artış gösterdiği bilinmektedir (24).

Yapılan bir çalışmada hastanede kazanılmış enfeksiyonların gerek uzamış yatış süresi, gerekse de artmış maliyet açısından anlamlı risk teşkil ettiği belirlenmiştir. Hastanede kazanıımış enfeksiyonlar; uzamış yatış süresi, antibiyotik tedavisinin maliyeti, antibiyotik düzey takibi ve organ toksisitesinin monitörizasyonu için yapılan biyokimyasal parametrelerin takibi, enfeksiyon nedeniyle yapılan ek görüntüleme ve cerrahi girişimler nedeniyle artmış maliyetle ilişkili olabileceği, hastanede kazanılmış enfeksiyonların önlenmesinin hasta maliyetlerini düşürmede faydalı olabileceği; bu enfeksiyonların önemli bir kısmının yoğun bakım ekibinin eğitimi ve enfeksiyon kontrol programlarının etkin olarak çalıştııımasıyla engellenebileceği bildirilmiştir (25).

Ülkemizde; Inan ve ark (26). yaptıkları bir çalışmada 2004 yılında YBÜ'de Acinetobacter enfeksiyonlarının görülme oranlarını \%5,8 gibi düşük bir oranda tespit ederken, bu oran 2010 yılında \% 76,6 gibi yüksek bir oranda görülmeye başlanmış ve her üç enfeksiyon etkeni patojeninden ikisini oluşturduğunu tespit etmişler. Hastanemizde de benzer şekilde 2009-2010 yılları arasında yapılan bir çalışmada HE'una neden olan mikroorganizmalar arasında A.baumannii \%23.2 oranı ile ilk sırada yer almakta idi (11).

Acinetobacter türlerinin neden olduğu hastane enfeksiyonlarında risk faktörlerine yönelik yapılan daha önceki çalışmalarda birçok olası risk faktörleri tanımlanmıştır $(27,28)$. Falagas ve ark. (27) yaptıkları bir metaanalizde; 20 vakakontrollü çalışma değerlendirilmiş olup çoğul ilaç dirençli $A$. baumanniinin, kolonizasyonu/enfeksiyonuna en sık neden olan faktörün 20 çalışmanın 11'inde önceki antibiyotik kullanımı olduğunu tespit etmişlerdir. Bu çalışmalarda en sık üçüncü kuşak sefalosporin ve karbapenemlerin (11 çalışmanın 4'ünde) risk faktörü olduğu, bu antibiyotik gruplarını takiben sırası ile florokinolon, aminoglikozit ve metronidazolün diğer risk faktörlerini oluşturduğu belirtilmiştir.

Yaptığımız çalışmada, HE tanısı alan hastaların tamamına, yatışı boyunca en az iki invaziv girişim uygulanmıştı. Üriner kateterizasyon (\%100), mekanik ventilasyon uygulaması $(\% 94,2)$, enteral beslenme $(\% 88,4)$ nazogastrik 
sonda uygulaması (\%87), santral venöz kateterizasyon $(\% 81,2)$, trakeotomi $(\% 42)$, reentübasyon $(\% 21,8)$, immünsüpresif tedavi uygulanması $(\% 44,9)$ ve cerrahi girişim $(\% 15,9)$ olası risk faktörlerindendi. Hastaların 48 $(\% 69,6)$ 'inde Acinetobacter enfeksiyonları için risk faktörlerinden olabilecek bir ve/veya birden fazla altta yatan hastalık bulunmakta idi. Bu hastalardan; 22 tanesi diyabet, 19'u kronik obstruktif akciğer hastalığı, 10'u malignite ve 4 tanesi kronik böbrek yetmezliği tanısı almıştı. Mekanik ventilasyon oranının yüksek olması (\%94,2); izolatlar arasında solunum yolu örneklerinin çoğunluğu $(\% 65,2)$ oluşturmasından kaynaklanmakta idi.

Acinetobacter'lerde direnç gelişimi açısından birçok olası risk faktörünün olduğu iddia edilmiştir. MDR gelişimi açısından; çoklu travma ile hastaneye başvuru, mekanik ventilasyon uygulanması, kan ve kan ürünü transfüzyonu, alınan antibiyotik sayısı ve önceki antibiyotik tedavisi, geniş spektrumlu antibiyotiklerin uygunsuz kullanımı, hospitalizasyonun özellikle yoğun bakım ünitesinde yapılması, immünsüpresif tedavi, altta yatan hastalıkların ciddiyeti, enfeksiyon öncesi septik şok ve daha önce geçirilmiş karbapenem dirençli A.baumannii enfeksiyonunun risk faktörleri olabileceği ifade edilmiştir (27-31).

Yaptığımız çalışmada; hastaların $41(\% 59,4)$ 'inin son üç ay içinde hastaneye yatış öyküsü ve YBÜ yatış öncesi 53 $(\% 76,8)$ 'ünün birden fazla antibiyotik kullanma öyküsü vardı. $65(\% 94,2)$ hasta YBÜ'de kültür alındığında birden fazla grup antibiyotik kullanmakta idi. Siprofloksasin $(\% 47,8)$, piperasilin-tazobaktam $(\% 40,6)$ ve karbapenemler $(\% 37,6)$ en çok kullanılan antibiyotiklerdi. Bulgularımız daha önce yapılmış çalışmalar ile uyumlu idi. Hastaların son üç ay içinde hastaneye yatış öyküsünün bulunması, yatış öncesi antibiyotik kullanımının yüksek olması ve siprofloksasin, piperasilin-tazobaktam ve karbapenem kullanımının mevcut veriler ile MDR A.baumanii enfeksiyonlarının gelişiminde risk faktörleri olabileceği düşünüldü.

Dede ve ark. (32) ise retrospektif bir çalışmada 2010 Ocak2011 Aralık tarihleri arasında, yoğun bakım ünitesinde yatan hastalara ait çeşitli klinik örneklerden izole edilen 172 A.baumannii suşunun antibiyotik duyarlııklarını incelemiş. Antibiyotik direnç oranları sırasıyla; amikasin için \%64, siprofloksasin için $\% 76$, sefoperazon sulbaktam için $\% 79$, piperasilin tazobaktam için \%84, meropenem ve imipenem için ise $\% 92$ olarak bulunmuştur. Hastanemizde yapılan bir çalışmada; Ocak 2009-Mart 2010 tarihleri arasında YBÜ' leri ve servislerden izole edilen 26 A.baumannii izolatının duyarlılık profili; amikasin için \%19.2, imipenem için \%27, siprofloksasin için $\% 7,7$, sefoperazon/sulbaktam için $\% 30.8$, tetrasiklin için \%84.6, trimetoprim/sulfametaksozol için \%38.5 olarak tespit edilmişti. Piperasilin-tazobaktam ve seftazidime ise tüm suşlar dirençli idi (11). Bu çalışmada 69 A.baumannii izolatının disk difüzyon yöntemi ile yapılan duyarlılık testinde; ampisilin/sulbaktam'a \%95,7, seftazi- dim'e $\% 95,7$, sefepim'e \%95,7, gentamisin'e $\% 92,8$, amikasin'e \%85,5, siprofloksasin'e \%95,7 ve trimetoprim/sülfametoksazol'e $\% 75,4$ oranında direnç tespit edildi. Tüm suşlar disk difüzyon ile imipenem, meropenem, seftriakson ve piperasilin/tazobaktam'a dirençli olarak bulundu. 2009 yılı hastanemiz verileri ile karşılaştııılı̆ğında tüm antibiyotik gruplarında direnç oranlarının arttığı görülmektedir.

Klinik mikrobiyoloji laboratuvarlarında epidemik potansiyeli olan A.baumannii izolatlarının çabuk ve doğru saptanması kontrol önlemlerinin alınması açısından son derece önemlidir. Bu suşların kolonize olabilmeleri, hastane ortamında yaşayabilmeleri, antibiyotiklere dirençli olmaları yayılmalarına katkıda bulunan faktörlerdir. Epidemik A.baumannii izolatları sporadik olanlardan çok daha dirençlidir ve herhangi bir çoklu ilaca dirençli $A$. baumannii suşunun nozokomiyal salgın yapma potansiyeli vardır. Ayrıca bu suşlar çoğunlukla ortak bir klondan köken alırlar (33).

Direncin ortaya çıkmasında hatalı antibiyotik kullanımları kadar, laboratuvar yöntemlerindeki yetersizlikler de önemli rol oynamaktadır. Direncin belirlenmesinde geç kalınması veya doğru olarak ortaya konulamaması durumunda, dirençli suşlara bağlı infeksiyonların tedavisi ve kontrolü sorun haline gelmektedir. Sorunların üzerinden gelinmesinde direncin mekanizması ve yayılma yollarının belirlenmesinin büyük önemi vardır. Bu noktada moleküler yöntemlerin büyük katkıları olmaktadır (34). Hangi yöntem kullanılırsa kullanılsın mutlaka klasik epidemiyolojik veriler dikkate alınmalıdır. PFGE genotipik yöntemler içinde ayrıştırma gücü ve tekrarlanabilirliği yüksek olduğu için günümüzde pek çok etyolojik ajan için altın standart olarak kabul edilen moleküler yöntemdir (15). Tayvan'da yapılan bir çalışmada; Hastanedeki MRSA enfeksiyonlarının kaynağı ve kontrol önlemlerinin etkinliğini denetlemek amacıyla sağlık personeli ve hastalardan alınan kültürlerde üretilen MRSA suşlarının PFGE ile tiplendirmesi yapılmış, iki predominant genotip saptanmıştır. Daha sonra taşıyıcılar topikal nasal mupirosin ile tedavi edilerek nozokomiyal MRSA infeksiyonlarında kayda değer bir azalma gözlenmiştir (35).

Wang ve ark. (36) 1999-2005 yılları arasında 11 hastaneden izole ettikleri 221 imipenem dirençli Acinetobacter izolatını PFGE ile tiplendikleri çalışmalarında; iki veya daha fazla subtipten oluşan 15 patern tanımlamış ve çalışma periyodu esnasında dört şehirde on hastanede klonal yayıllmın olduğunu saptamışlardır. Bu izolatlardan 74 tanesi enfeksiyon etkeni iken 28 tanesi kolonizasyon nedeni olarak bulunmuştur. Ancak klonal yayılım olan hastaneler arasındaki, hasta transferlerine rastlanmamıştır.

Bu çalışmada A.baumannii izolatlarının PFGE ile tiplendirilmesi yapıldı. PFGE yöntemiyle 69 A.baumannii suşunun $62(\% 89,9)$ 'sinin küme içinde olduğu saptandı. Bu suşlar 16 küme içinde yer almakta idi. Suşların $7(\% 10,1)$ 'si özgül PFGE profili gösterdi. Kümeleşmede suş aralığı 2-9 arasında değişmekte idi. Tiplendirmeye alınan suşlar arasında 
23 pulsotip saptandı. Çalışmada elde edilen kümelerden beş tanesinde $(3,7,8,14$ ve 15. küme) GHYBÜ ve AYBÜ'nün her ikisinden izole edilen suşlar bulunmakta idi. Ayrıca 9. küme ise PYBÜ ve AYBÜ'den izole edilen suşları içermekte idi. 6. ve 13. kümelerde ise her üç YBÜ'den suşlar bulunmakta idi. Yıllar içinde benzer genotipteki, çoğul ilaç direnci olan A.baumannii'nin farklı ünitelerdeki hastalardan izole edilmesi bu bakterinin hastanemiz YBÜ'lerinde endemik duruma geçtiğinin göstergesidir.

PFGE tiplendirmesinin sonucunda hastanemizdeki Acinetobacter spp. suşlarının yaklaşık on tanesinden dokuzu gibi oldukça yüksek bir kısmının klonal yönden ilişkili oldukları saptandı. Hastanemizde yoğun bakımlar arasında hasta transferleri sık yapılmaktadır. Ayrıca servis-YBÜ-servis arasında da hasta transferleri çok sık olmaktadır. Bu da hastanemizde A.baumannii klonlarının yayılmasını arttırmaktadır. İzolatlar arasındaki klonal yakınlığın bir göstergesi olan kümeleşme oranı \%89,9 olarak bulundu. Bu kümeleşme oranı, izolatlar arasındaki klonal yakınlığın oldukça yüksek olduğunun, diğer bir deyişle hastalar arasında çapraz bulaş oranının yüksekliğinin önemli bir göstergesidir. Bu da elimizdeki epidemiyolojik verilerle karşılaştırıldığında üniteler arası yoğun bir bulaşın söz konusu olduğunu göstermektedir. Bazı kümelerde suş sayısı dokuz gibi yüksek rakamlara ulaşmaktadır. Bu durum çapraz bulaş derecesinin büyüklüğünü ciddi biçimde ortaya koymaktadır. Bu küme içinde yer alan suşlar yaklaşık 14 ay hastanemizde varlığını sürdürmüştür. Diğer bir kümenin hastanemizde kalış süresi 34 aya kadar uzamıştır. Bu veriler A.baumannii gibi önemli nozokomiyal patojenin hastanede kolayca yayılabildiğini ve uygun korunma ve kontrol önemlerinin alınmaması halinde yıllarca hastane ortamında kalabileceğini vurgulamaktadır.

Antibiyotiklere çoğul dirençli bakterilerin neden olduğu enfeksiyonların tedavisinde yaşanan güçlükler, hastane kaynaklı enfeksiyonların gelişimini azaltan enfeksiyon kontrol programlarının uygulanmasını zorunlu hale getirmiştir (12, 37). Epidemiyolojik sürveyans çalışmaları, enfeksiyon kontrol programlarının ayrımaz bir parçasını oluşturur. Salgının kaynağının bulunması dirençli A.baumannii kökenlerinin neden olduğu epideminin sonlandırıması açısından büyük önem taşımaktadır. Günümüz moleküler tiplendirme yöntemleri içerisinde, ayrım gücü ve tekrarlanabilirliği yüksek olan PFGE'nin epidemiyolojik sürveyans çaIışmalarında kullanılması Acinetobacter salgınlarının ve salgına neden olan kaynağın tespitine izin vererek, uygun enfeksiyon kontrol önlemlerinin geliştirilmesini sağlayabilmekte ve gelecekte bu programların ayrılmaz bir parçası olabileceği düşünülmektedir.

Sonuç olarak; A.baumannii enfeksiyonları bugün itibariyle diğer ülkelerde olduğu gibi ülkemizde ve hastanemizde önemli bir sorun haline gelmiştir. Bu sorun yoğun bakım ünitelerinde daha da önem kazanmıştır. Mikroorganizma hastanemizde endemik bir patojen haline gelmiş, kolistin ve tigesiklin dışında kullanılabilecek antibiyoterapi neredeyse kalmamıştır. Mikroorganizmalar arasındaki klonal ilişkiyi ortaya çıkarmayı hedefleyen moleküler tipleme yöntemleri, özellikle tedavideki zorluklar nedeniyle kontrol edilmesinde özel çabalar gerektiren dirençli bakterilere bağlı infeksiyonların kontrolünde, önemli yararlar sağlamaktadırlar. Moleküler tipleme yöntemini uygulayan hastaneler, dirençli bakterilere bağı infeksiyonları önemli oranlarda azaltmışlardır. PFGE yaygın olarak kullanılan moleküler metotlardandır. Ancak, hangi tipleme yöntemi kullanıırsa kullanılsın, mutlaka klasik epidemiyolojik bulgularla beraber değerlendirilmesi gerekmektedir.

Salgının zamanında fark edebilmesi için düzenli ve sürekli sürveyans çalışmaları yapıımalıdır. Ünitede izolatların belirgin artışı saptanırsa, salgın olduğu düşünülmeli, çevre ve personel taraması yapılmalı ve bulaşın kaynağı belirlenmedir. PFGE gibi bir moleküler yöntemle salgının epidemiyolojisi aydınlatılmalıdır. Bu tür moleküler temelli çalışmaların prospektif çalışmalarla desteklenmesi ve daha fazla yapılmasına intiyaç vardır. Bu sayede daha ucuz, kolay ve hızlı moleküler temelli yöntemlerin rutinde kullanılmasına imkan sağlanılabilir.

\section{Açıklamalar}

Etik Onam: Bu çalışma Van Yüzüncüyıl Üniversitesi Bilimsel Araştırma Projeleri Başkanlığı tarafından 2012-TFU037 numaralı proje olarak desteklenmiş ve Van Yüzüncüyıl Üniversitesi Illaç Dışı Klinik Araştırmalar Etik Kurul Başkanlığı'nın 09.05.2013 tarih ve 08 no'lu etik kurul kararı ile çalışmaya başlanmıştır.

\section{Kaynaklar}

1. Peleg AY, Seifert $H$ and Paterson DL. Acinetobacter baumannii: emergence of a successful pathogen. Clin Microbiol Rev. 2008; 21(3):538-82.

2. Allen MD, Hartman BJ, Acinetobacter spp, In: Mandell, douglas, and bennett's principles and practice of infectious diseases: 7th ed., Churchill Livingstone, Philadelphia, 2010; 2881-85.

3. Fournier PE, Richet $H$ and Weinstein RA. The epidemiology and control of Acinetobacter baumannii in health care facilities. Clin Infect Dis. 2006;42(5):692-99,

4. Seifert H, Dijkshoorn L, Gerner-Smidt P, Pelzer N, Tjernberg I, Vaneechoutte M, Distrubution of Acinetobacter species on human skin: comparison of phenotypic and genotypic identification methods. J Clin Mikrobiyol. 1997; 35(11): 2819-25.

5. Corbella X, Pujol M, Ayats J, Sendra M, Ardanuy C, Domínguez MA, 'et al.' Relevance of digestive tract colonization in the epidemiology of nosocomial infections due to multiresistant Acinetobacter baumannii. Clin Infect Dis. 1996; 23(2), 329-34.

6. T.C. Sağık Bakanlığı, Sağlık Hizmetleri Genel Müdürlüğü, Sağlık Hizmet Standartları Dairesi Başkanlığı Ulusal Hastane Enfeksiyonları Sürveyans Ağı (UHESA) Raporu, Özet Veri 20, 2012. https://docplayer.biz.tr/108543950-Ulusal-hastane-enfeksiyonlari-surveyans-agi-uhesa-raporu-ozet-veri-2012.html

7. Schulte B, Goerke C, Weyrich P, Gröbner S, Bahrs C, Wolz C, 'et al.' Clonal spread of meropenem-resistant Acinetobacter baumannii strains in hospitals in the Mediterranean region and transmission to South-west Germany. J Hosp Infect. 2005; 61(4):356-7.

8. Souli M, Galani I, and Giamarellou H, Emergence of extensively drugresistant and pandrug-resistant Gram-negative bacilli in Europe. İn:Euro 
surveillance: bulletin européen sur les maladies transmissibles= Euro Surveill. Kristinsson, K.G., Monnet, D.L.(Eds), 2008; 13(47):30-40

9. Ruiz J, Núñez ML, Pérez J, Simarro E, Martínez-Campos L, and Gómez J, Evoluation of resistance among clinical isolates of Acinetobacter over a 6-year period, Eur J Clin Microbiol Infect Dis. 1999; 18(4):292-5.

10. Corbella X, Montero A, Pujol M, Domínguez MA, Ayats J, Argerich $\mathrm{MJ}$, 'et al.' Emergence and rapid spread of carbapenem resistance during a large and sustained hospital outbreak of multiresistant Acinetobacter baumannii. J Clin Microbiol. 2000; 38(11): 4086-95,

11. Karahocagil MK, Yaman G, Göktaş U, Sünnetçioğlu M, Çıkman A, Bilici A. ve 'ark.' Hastane enfeksiyon etkenlerinin ve direnç profillerinin belirlenmesi, Van Tıp Dergisi. 2011; 18(1):27-32,

12. Leblebicioglu H, Rosenthal VD, Arıkan ÖA, Özgültekin A, Yalcin AN, Koksal I, 'et al.' Device-associated hospital-acquired infection rates in Turkish intensive care units. Findings of the International Nosocomial Infection Control Consortium (INICC). J Hosp Infect. 2007; 65(3): 2517.

13. Dikmen $Y$, Aygün $G$, Öztürk R. Yoğun bakım ünitesinde ventilatör ilişkili pnömonilerin değerlendirilmesi. Klimik Dergisi. 2004; 17(2):117-9, 14. Meric M, Willke A, Caglayan C, Toker K. Intensive care unit-acquired infections: incidence, risk factors and associated mortality in a Turkish university hospital. Jpn J Infect Dis. 2005;58(5):297-302.

15. Goering RV. Molecular epidemiology of nosocomial infection: analysis of chromosomal restriction fragment patterns by pulsed-field gel electrophoresis. Infect Control Hosp Epidemiol. 1993; 14(10): 595-600

16. $\mathrm{CDC} / \mathrm{NHSN}$ surveillance definition of health care-associated infection and criteria for specific types of infections in the acute care setting. Am J Infect Control. 2008; 36: 309-32,

17. Performance Standards for Antimicrobial Disk Susceptibility Tests; Approved Standard-Eleventh Edition. CLSI document M02-A11 (ISBN 1-56238-781-2 [Print]; ISBN 1-56238-782-0 [Electronic]). 2012; 32(1): 44-5, Clinical and Laboratory Standards Institute, Wayne, Pennsylvania, USA,

18. Performance Standards for Antimicrobial Susceptibility Testing; Twenty-Third Informational Supplement. CLSI document M100-S23 (ISBN 1-56238-865-7 [Print]; ISBN 1-56238-866-5 [Electronic]).2013; 33(1):66-7, Clinical and Laboratory Standards Institute, Wayne, Pennsylvania, USA

19. Navon-Venezia S, Leavitt A, Carmeli Y. High tigecycline resistance in multidrug-resistant Acinetobacter baumannii, J Antimicrob Chemother. 2007; 59(4):772-4.

20. Seifert $H$, Dolzani $L$, Bressan $R$, van der Reijden $T$, van Strijen $B$, Stefanik D, 'et al.' Standardization and interlaboratory reproducibility assessment of pulsed-field gel electrophoresis-generated fingerprints of Acinetobacter baumannii. J Clin Microbiol. 2005; 43(9): 4328-35,

21. Durmaz R, Otlu B, Koksal F, Hosoglu S, Ozturk R, Ersoy Y, 've ark.' The optimization of a rapid pulsed-field gel electrophoresis protocol for the typing of Acinetobacter baumannii, Escherichia coli and Klebsiella spp. Jpn J Infect Dis. 2009; 62(5), 372-7.

22. Tenover FC, Arbeit RD, Goering RV, Mickelsen PA, Murray BE, Persing DH, 'et al.' Interpreting chromosomal DNA restriction patterns produced by pulsed-field gel electrophoresis: criteria for bacterial strain typing. J Clin Microbiol. 1995; 33(9): 2233-9

23. Taşova Y, Akgün Y, Saltoğlu N, Yılmaz G, Kara O, Dündar IH, Nozokomiyal Acinetobacter infeksiyonları. Flora. 1999; 4(3):170-6

24. Xu T, Xia W, Rong G, Pan S, Huang P, Gu B, A 4-year surveillance of antimicrobial resistance patterns of Acinetobacter baumanni in a university-affiliated hospital in China. J Thorac Dis. 2013; 5(4): 506-12.

25. Eren OÖ, Kalyoncu U, Andıç N, Şardan YÇ, Yoğun bakım ünitesinde hasta maliyetini etkileyen faktörler. Selçuk Tıp Dergisi. 2009; 25(4):195202 ,

26. İnan A, Özgultekin A, Akçay SS, Engin DÖ, Turan G, Ceran N, et al. Alterations in bacterial spectrum and increasing resistance rates in isolated microorganisms from device-associated infections in an intensive care unit of a teaching hospital in İstanbul (2004-2010). Jpn J Infect Dis.
2012; 65(2), 146-151

27. Katsaragakis $S$, Markogiannakis $H$, Toutouzas KG, Drimousis $P$, Larentzakis A, Theodoraki EM, 'et al.' Acinetobacter baumannii infections in a surgical intensive care unit: predictors of multi-drug resistance. World J Surg. 2008; 32(6), 1194-202

28. Falagas ME, and Kopterides $P$, Risk factors for the isolation of multidrug-resistant Acinetobacter baumannii and Pseudomonas aeruginosa: a systematic review of the literature. J Hosp Infect. 2006; 64(1):7-15,

29. Abbo A, Carmeli Y, Navon-Venezia S, Siegman-Igra Y, Schwaber $\mathrm{MJ}$, Impact of multi-drug-resistant Acinetobacter baumannii on clinical outcomes. Eur J Clin Microbiol Infect Dis. 2007; 26(11): 793-800

30. Wróblewska M, Novel therapies of multidrug-resistant Pseudomonas aeruginosa and Acinetobacter spp. infections: the state of the art. Arch Immunol Ther Exp (Warsz). 2006; 54(2): 113-120,

31. Brahmi N, Beji O, Abidi N, Kouraichi N, Blel Y, El Ghord H, 'et al.' Epidemiology and risk factors for colonization and infection by Acinetobacter baumannii in an ICU in Tunisia, where this pathogen is endemic. J Infect Chemother. 2007; 13(6): 400-4

32. Dede B, Kadanalı A, Karagöz G, Çomoğlu Ş, Bektaşoğlu MF, Yücel FM. Investigation of antibiotic resistance of Acinetobacter baumannii strains isolated from various clinical samples in intensive care unit. Bakırköy Tıp Dergisi. 2013; 9(1): 20-23,

33. Koeleman JG, van der Bijl MW, Stoof J, Vandenbroucke-Grauls CM, Savelkoul PH. Antibiotic resistance is a major risk factor for epidemic behavior of Acinetobacter baumannii. Infect Control Hosp Epidemiol. 2001; 22(5), 284-8

34. Durmaz R. Direnç gelişimini önlemede moleküler mikrobiyolojinin katkısı. Ankem Dergisi. 2009; 23 (Ek 2):111-5,

35. Wang JT, Lin SF, Chiu HL, Wang LC, Tai HM, Jiang CF, 'et al.' Molecular epidemiology and control of nosocomial methicillin-resistant Staphylococcus aureus infection in a teaching hospital. J Formos Med Assoc. 2004; 103(1): 32-6,

36. Wang H, Guo P, Sun H, Wang H, Yang O, Chen M, 'et al.' Molecular Epidemiology of Clinical Isolates of Carbapenem-Resistant Acinetobacter spp. from Chinese Hospitals. Antimicrob Agents Chemother. 2007; 51(11), 4022-8,

37. Rosenthal V, Guzmán S, Crnich C, Device-associated nosocomial infection rates in intensive care units of Argentina. Infect Control Hosp Epidemiol. 2004; 25(3): 251-5, 